\title{
PERAN PENGAWASAN ORANG TUA TERHADAP PENGENDARA MOTOR DI BAWAH UMUR
}

\author{
Sherli Aulia Marwantika ${ }^{1}$, Asna Istya Marwantika ${ }^{2}$ \\ ${ }^{1}$ Universitas Negeri Surabaya \\ sherli.19002@mhs.unesa.ac.id \\ ${ }^{2}$ Institut Agama Islam Negeri Ponorogo \\ marwantika@iainponorogo.ac.id
}

\begin{abstract}
ABSTRAK
Kecelakaan lalu lintas yang melibatkan anak di bawah umur semakin meningkat di setiap tahunnya. Tercatat dalam rentang tahun 2015-2019, lebih dari 139.000 pengendara di bawah umur menjadi pelaku kecelakaan lalu lintas, atau diakumulasi sekitar $16 \%$ dari jumlah total kecelakaan di Indonesia. Penelitian ini bertujuan untuk membahas perilaku anak pasca diperbolehkannya mengendarai motor dan bagaimana pengawasan orang tua dalam menyikapi hal tersebut. Penelitian ini menggunakan pendekatan kualitatif dengan desain penelitian studi kasus.Teknik pengumpulan data dilakukan melalui observasi di lapangan dan melakukan wawancara secara langsung kepada informan. Hasil dari penelitian menunjukkan bahwa: 1) Faktor perizinan dari keluarga atau orang tua, efisiensi waktu yang digunakan, serta ajakan dari teman dan gaya hidup mempengaruhi anak di bawah umur sudah menggunakan motor, 2) Dampak dari pengendara motor di bawah umur ini merupakan wujud untuk menunjukkan eksistensi diri dengan mengikuti trek-trekan serta berani memodifikasi motor dengan dalih biar terlihat lebih keren, 3) Orang tua memiliki peranan yang sangat penting dalam mengawasi pengendara di bawah umur, Pola pengasuhan yang diterapkan oleh orang tua sangat mempengaruhi pola perilaku dan juga proses pembentukan karakter anak.
\end{abstract}

Kata Kunci: Pengendara Motor di Bawah Umur; Pengawasan Orang tua

\begin{abstract}
Traffic accidents involving minors are increasing every year. It was recorded that in the period 2015-2019, more than 139,000 underage motorists were the perpetrators of traffic accidents or an accumulation of around $16 \%$ of the total number of accidents in Indonesia. This study aims to discuss the behavior of children after being allowed to ride a motorbike and how parental supervision is concerned with this. This study used a qualitative approach with a case study research design. Data collection techniques were carried out through field observations and direct interviews with informants. The results of the study show 1) The licensing factor from family or parents, the efficiency of time used, as well as invitations from friends and lifestyle, affect minors who already use motorbikes, 2) The impact of underage motorists is a manifestation of self-existence by following the tracks and daring to modify the motorbike on the pretext of making it look cooler. 3) Parents have a very important role in supervising underage rider.
\end{abstract}

Keywords: Underage Motor Riders; Parental Control

Copyright (c) 2020 Sherli Aulia Marwantika, Asna Istya Marwantika 


\section{PENDAHULUAN}

Tingginya mobilitas yang dilakukan oleh masyarakat dapat menyebabkan beberapa persoalan yang muncul di lingkungan sosial. Salah satunya adalah adanya pengendara motor di bawah umur. Melihat kultur budaya dan kondisi lingkungan, membuat masyarakat di negara berkembang memang lebih memilih untuk menggunakan kendaraan pribadi daripada kendaraan umum ${ }^{1}$. Sepeda motor menjadi pilihan sebagian besar masyarakat karena dianggap lebih efisien, efektif dan harganya dapat dijangkau oleh kalangan kelas menengah ke bawah. Namun, penggunaan sepeda motor sering kali tidak dibatasi sehingga menyebabkan kalangan di bawah umur dapat menggunakannya juga.

Berbagai fenomena pengendara sepeda motor umumnya terjadi negaranegara berkembang. Hal ini dikarenakan kurang adanya fasilitas kendaraan umum yang memadai di negara tersebut ${ }^{2}$. Di kawasan Asia Tenggara, setidaknya tercatat bahwa sepeda motor memiliki presentase sebanyak 50\% dari total kendaraan yang terdaftar di Malaysia, Indonesia, Vietnam, Thailand dan Filipina dengan tertinggi di Vietnam pada $95 \%{ }^{3}$. Fakta tersebut menjadi bukti bahwasanya sepeda motor sangat digemari oleh penduduk di kawasan Asia Tenggara.

Sebaliknya, korban dari kecelakaan sepeda motor menjadi keprihatinan yang signifikan di negara-negara tersebut. Dimana pengguna sepeda motor mewakili lebih dari setengah total kematian lalu lintas setiap tahunnya. Korban dari kecelakaan tersebut tidak hanya berasal dari orang dewasa, mirisnya juga didominasi oleh remaja usia 11-19 tahun ${ }^{4}$. Hal ini menjadi bukti bahwasanya pengendara sepeda motor di bawah umur memiliki resiko cedera yang lebih tinggi jika dibandingkan dengan pengendara yang lebih tua.

\footnotetext{
${ }^{1}$ Kurniasih, Dewi \& Arninputranto, Wibowo. 2019. Analisis Perilaku dan Lingkungan

Berkendara Sepeda Motor Pada Pelajar SMA di Surabaya Untuk Menentukan Metode Sosialisasi dan Pembelajaran Safety Riding yang Efektif. Jurnal Pendidikan Profesional. Dari

http://p3m.ppns.ac.id/wp-content/uploads/2019/08/2.Analisa-Perilaku-dan-Lingkungan-

Berkendara-Sepeda-Motor.pdf

${ }^{2}$ Isa, Mohd Hafzi. Sarani, Rohayu. Jawi, Zulhaidi Mohd \& Wong, Shaw VOON. 2011. Injurity

Severity Analysis of Accident Involving Young Motorcycle in Malaysia. Journal of the Eastern

Asia Society Transportasion Studies, vol 9. Dari

https://www.researchgate.net/publication/280940108_Injury_Severity_Analysis_of_Accidents_In volving_Young_Motorcycle_Riders_in_Malaysia, dan_Wada, Tomoki. Nakahara, Shinji.

Bounta, Bouasone. Phommahaxay, Kheumai \& Phonelervong, Vanhnasith. 2015. Road Traffic Injury Among Child Motorcyclist in Vientiane Capital, Laos: A Cross-Sectional Study Using A Hospital-Based Injury Surveillance Database. International Journal of Injury and Safety

Promotion. Volume 24 issue 2. Dari https://www.tandfonline.com/doi/abs/10.1080/17457300.2015.1080728

${ }^{3}$ World Health Organization (WHO). 2011. Youth and Road Safety. Dari https://www.who.int/management/programme/ncd/Youth\%20and\%20Road\%20Safety.pdf

${ }^{4}$ Leong, QM, Tsung Shyen, KG, Appasamy, V., dan Chiu, MT. 2011. Young Adult and Riding Position: Factors That Affect Mortality Among Inpatient Adult Motorcycle Casualties: A Major Trauma Center Experience. World J Surg, Vol 33 No 4. Dari https://www.ncbi.nlm.nih.gov/pubmed/19184191
} 
Berbagai kebijakan telah dilakukan untuk menanggulangi masalah pengendara motor di bawah umur. Berdasarkan dari situs WHO (2011), diperoleh beberapa cara untuk menanggulangi masalah ini, diantaranya adalah menegakkan hukum terkait dengan peraturan berkendara, menyediakan mobilitas dan aksesbiitas untuk semua warga dengan cara yang aman serta ramah lingkungan, memberikan himbauan kepada orang tua untuk selalu membimbing dan mengawasi anaknya dalam hal pembatasan berkendara dan memberikan pengetahuan tentang ramburambu lalu lintas kepada anak.

Di Indonesia pada beberapa tahun terakhir, banyak terjadi kecelakaan lalu lintas yang disebabkan oleh pengendara di bawah umur. Keterlibatan pelajar sebagai pengendara sepeda motor sangat bertentangan dengan Undang-Undang Republik Indonesia nomor 22 tahun 2009 pasal 81 ayat 2, bahwa seseorang yang berhak memiliki SIM C pada usia 17 tahun. Sedangkan siswa SMP merupakan remaja awal yang rentang usianya antara 12-15 tahun. Tentunya mereka belum berhak untuk mengendarai motor serta memiliki SIM C. Namun pada kenyataannya, masih banyak siswa SMP yang mengendarai kenderaan bermotor, hal ini jelas melanggar hukum.

Dalam rentang 2015-2019 setidaknya tercatat lebih dari 139.000 anak menjadi pelaku kecelakaan lalu lintas, sekitar $16 \%$ dari jumlah total kecelakaan di Indonesia ${ }^{5}$. Ini merupakan data yang sangat memprihatinkan. Pelajar juga mendominasi tingkat pelanggaran lalu lintas di Indonesia sepanjang tahun 2019. Bukan hanya hal itu saja, baru-baru ini tersebar di media sosial tentang bagaimana pola perilaku remaja di bawah umur dalam berkendara. Diantaranya adalah kasus remaja asal Pasuruan yang melakukan trek-trekan di makam umum ${ }^{6}$, kasus 2 orang remaja yang mandi dan berkeramas dengan mengendarai motor ${ }^{7}$, dan adapula kasus tentang remaja yang nekat berboncengan melebihi kapasitas jumlah pengendara.

Mereka seakan-akan tidak menghiraukan bagaimana bahaya yang ditimbulkan dari perbuatannya tersebut. Padahal mengendarai motor dengan berbagai gaya tersebut sangat beresiko besar terhadap pengguna jalan lainnya. Pada rentang umur 11-16 tahun, seorang anak masih dalam kondisi emosi yang belum

\footnotetext{
${ }^{5}$ Maulana, Aditya. 2019. Berita harian kompas tanggal 30 Agustus 2019. Anak Di Bawah Umur Jadi Pelaku dan Korban Kecelakaan Lalu Lintas. Dari https://otomotif.kompas.com/read/2019/08/30/063200315/anak-di-bawah-umur-jadi-pelaku-dankorban-kecelakaan-lalu-lintas

${ }^{6}$ Rajasa, Agung. 2019. Berita Harian CNN Indonesia tanggal 25 Juli 2019. Video Treak-Trekan Di Makam Viral, Remaja Pasuruan Minta Maaf. Dari https://www.cnnindonesia.com/nasional/20190725071401-20-415275/video-trek-trekan-dimakam-viral-remaja-pasuruan-minta-maaf

${ }^{7}$ Bramasta, Dandy Bayu. 2019 Berita Harian Kompas tanggal 13 Desember 2019. Viral Remaja Keramas Sambil Mengendarai Motor. Dari https://www.kompas.com/tren/read/2019/12/13/203306765/viral-remaja-keramas-sambil$\underline{\text { mengendarai-motor }}$
} 
stabil sehingga berbagai pelanggaranpun rentan terjadi ${ }^{8}$. Bukan hanya tentang pelanggaran saja, faktor umur juga menjadi pemicu terjadinya kecelakaan di jalan. Keberadaan usia memiliki korelasi dengan munculnya perilaku berkendara yang agresif dan mengarah pada terjadinya kecelakaan ${ }^{9}$. Beberapa penyebab terjadinya kecelakaan lalu lintas oleh pengendara di bawah umur diantaranya adalah kurangnya pengalaman dalam berkendara dan pemahaman terhadap rambu-rambu lalu lintas ${ }^{10}$.

Berbagai kebijakan telah dilakukan oleh pemerintah Indonesia untuk mengatasi masalah tersebut. Diantaranya adanya aturan batas umur untuk berkendara yang tercantum pada Undang-Undang Republik Indonesia nomor 22 tahun 2009 pasal 80 yang berbunyi "setiap orang yang mengemudikan kendaraan bermotor di jalan wajib memiliki Surat Izin Mengemudi sesuai dengan kendaraan bermotor yang dikemudikan", adanya operasi lalu lintas dari pihak kepolisian untuk mengecek kelengkapan berkendara dan patuh terhadap rambu lalu lintas ${ }^{11}$. Namun, pada kenyataannya masih saja banyak yang melanggar peraturan yang telah ditetapkan pemerintah tersebut ${ }^{12}$.

Adanya kasus pengendara motor di bawah umur, tentunya tidak lepas dari bagaimana peran orang tua dalam mendidik anak-anaknya.Pembentukan perilaku remaja cenderung mendorong remaja tersebut untuk melakukan hal-hal yang mengandung resiko tinggi, misalnya balap liar dan kebut-kebutan. Berbagai penelitian menyebutkan bahwasanya penyebab utama penyimpangan pada anak dibawah umur diantaranya karena ketidak matangan remaja yang mengarah kepada pengambilan resiko ${ }^{13}$ dan ketidak pedulian orang tua ${ }^{14}$.

\footnotetext{
${ }^{8}$ Piyapromdee, Urawit. Adulyanukosol, Varinthorn \& Lewsisirat, Supphamard. 2015. Increasing Road Traffic Injuries in Underage Motorcyclists. JRCOST vol 39 no 1-

2.Dari https://pdfs.semanticscholar.org/0432/cd84d4f19f57baf97c2637a7a871a4ee7e63.pdf

${ }_{9}^{9}$ Nordfjærn, T., Jorgensen, S., \& Rundmo, T. (2012). Cultural and socio-demographic predictors of car accident involvement in Norway, Ghana, Tanzania and Uganda. Safety Science vol 50 no 9. Dari https://www.sciencedirect.com/science/article/pii/S0925753512001130

${ }^{10}$ Isa, Mohd Hafzi. Sarani, Rohayu. Jawi, Zulhaidi Mohd \& Wong, Shaw VOON. 2011. Injurity Severity Analysis of Accident Involving Young Motorcycle in Malaysia. Journal of the Eastern Asia Society Transportasion Studies, vol 9. Dari

https://www.researchgate.net/publication/280940108_Injury Severity_Analysis_of_Accidents In volving Young Motorcycle Riders in Malaysia

${ }^{11}$ Manuhoro, Agasetyo. Purnaweni, Hartuti \& Rengga, Aloysius. 2016. Implementasi Kebijakan Batas Usia Terendah Pengemudi Motor Di Kota Semarang, Journal of Public Policy, volume 2 No 1. Dari https://ejournal3.undip.ac.id/index.php/jppmr/article/viewFile/10447/10146

${ }^{12}$ Wiradiadmaja, Agung. 2020. Parenting Education: Building Character and Holding in Millenial Mental Problems, Advances In Social Scienci, Educational and Humanities Research, vol 404. Dari https://www.atlantis-press.com/proceedings/icossei-19/125934688

${ }^{13}$ Damron, Jessica. 2011. The Development of devian in adolescents: The Influence Of Students Characteristics and School Climate, Electronic Theses and Dissertations of University Louisville. Dari https://pdfs.semanticscholar.org/47b4/02044fae9df4c0026ef2c7874b6d43dddd75.pdf

${ }^{14}$ Sedanayasa, Gede. Tegeh, Made \& Gading Ketut. 2015. Model Pengasuhan Analisis

Transaksional (AT) untuk Menanggulangi Penyimpangan Perilaku Seksual di Kalangan Remaja Kabupaten Buleleng (Studi Pada Sekolah SMP/SMA yang Memiliki Siswa Terindikasi). Jurnal
} 
Pola pengasuhan yang diberikan oleh orang tua dalam menekankan pentingnya perilaku patuh pada remaja terhadap peraturan menjadi faktor yang penting dan sangat berpengaruh jika nilai-nilai kepatuhan ini dijadikan acuan, namun jika nilai kepatuhan ini tidak ditanamkan sejak dini pada remaja, tentunya mereka akan merasa tidak takut dalam melanggar peraturan ${ }^{15}$. Orang tua dapat menarik garis tipis antara memberikan kebebasan yang cukup serta memberikan perlindungan pada remaja dari ketidak dewasaan remaja tersebut dalam menilai suatu tindakan ${ }^{16}$. Orang tua yang menerapkan pola pengasuhan yang baik seperti interaksi yang baik dan suportif maka akan memperkuat pembentukan psikologi remaja sehingga akan terhindar dari perilaku yang menyimpang ${ }^{17}$.

Perilaku pengendara motor di bawah umur telah merambah ke pelosok desa. Banyak remaja dibawah umur 17 tahun yang berlalu lalang mengendarai motor setiap harinya ${ }^{18}$. Alasan untuk mengendarai sepeda motorpun bermacam-macam, hal tersebut dipengaruhi oleh faktor internal dan eksternal dari si pengendara. Faktor internal yang mempengaruhi anak tersebut diantaranya adalah dorongan dari diri sendiri untuk bisa mengendarai sepeda motor, sedangkan faktor eksternalnya adalah terpengaruh dari teman-teman yang pada umumnya bisa mengendarai motor, jarak rumah ke sekolah yang relatif jauh, serta orang tua yang telah memberikan izin kepada mereka untuk mengendarai motor. Terkadang kehadiran mereka sangat mengganggu masyarakat, karena adanya kebut-kebutan di jalan, balap liar dan gangguan suara akibat knalpot yang tidak sesuai dengan standart.Tentunya ini semua tidak lepas dari pengawasan orang tua si anak. Karena orang tua memiliki peranan penting dalam membentuk pola perilaku anak.

Terdapat beberapa penelitian yang membicarakan tentang pengendara sepeda motor pada anak dibawah umur dengan perspektif yang berbeda. Dari perspektif keselamatan berkendara, penggunaan sepeda motor oleh remaja pada dasarnya memiliki resiko kecelakaan yang sangat tinggi akibat faktor internal dalam diri remaja terkait dengan pengetahuan serta kemampuan berkendara yang

Sosial dan Humaniora, Vol 4 No 1. Dari https://ejournal.undiksha.ac.id/index.php/JISH/article/view/4925/3712

${ }^{15}$ Utami, Adristinindya Citra Nur \& Raharjo, Santoso Tri. 2019. Pola Asuh Orang Tua dan Kenakalan Remaja, Jurnal Pekerjaan Sosial, volume 2 nomor 1. Dari https://www.jurnal.unpad.ac.id

${ }^{16}$ McCann, Damhnat. Bull, Rosalind \& Winzenberg, Tania. 2012. The Daily Patterns Of Time Use For Parents Of Children With Complex Nedds: A Systematic Review. Journal Of Child Healts Care, Volume 16, Issue 1. Dari https://journals.sagepub.com/doi/10.1177/1367493511420186

${ }^{17}$ Steele, Megan E., Simons, Leslie Gordon., Sutton, Tara \& Gibbons, Frederick. 2020. Talib, M. Abdullah R \& MansoR, M. 2011. Relationship Between Parenting Style and Childrens's Behavior Problems. Asian Social Science, volume 7 nomor 12. Dari https://www.researchgate.net/publication/267845974_Relationship_between_Parenting_Style_an d_Children's Behavior_Problems

${ }^{18}$ Baharuddin. 2019. Pentingnya Pola Komunikasi Orang Tua Terhadap Perkembangan Pubertas Remaja. Jurnal Studi Gender dan Anak, Volume 12 No 1. Dari https://www.researchgate.net/publication/335831848_Pentingnya_Pola_Komunikasi_Orang_Tua _Terhadap_Perkembangan_Pubertas_Remaja/link/5d7ed9a092851c87c38b0335/download 
dimiliki ${ }^{19}$. Selanjutnya dari perspektif persepsi anak dibawah umur terhadap keselamatan berkendara sepeda motor, pada dasarnya anak dibawah umur memiliki pengalaman yang kurang baik saat mengendarai sepeda motor dikarenakan oleh banyaknya pelanggaran lalu lintas yang dilakukan dan terjadinya kecelakaan ${ }^{20}$. Dari perspektif usia dan jenis kelamin dalam berkendara, pengemudi dengan usia muda dan berjenis kelamin laki-laki cenderung agresif dalam mengemudi. Hal ini dikarenakan memiliki emosional yang cenderung lebih tinggi.

Perbedaan penelitian ini dengan penelitian sebelumnya, pertama terletak pada subyek penelitian, yang mana penelitian ini lebih memfokuskan pada pengendara sepeda motor pada remaja Sekolah Menengah Pertama. Kedua, penelitian ini lebih memfokuskan tentang pola perilaku anak pasca diperbolehkannya mengendarai kendaraan bermotor oleh orang tua dan bagaimana pengawasan orang tua dalam menyikapi fenomena pengendarai motor pada anak di bawah umur.

Teori yang digunakan dalam penelitian ini ada teori kontrol sosial Travis Hirschi (1969). Teori kontrol sosial berasal dari asumsi bahwa individu di masyarakat mempunyai kecenderungan kemungkinan untuk menjadi "baik" atau "jahat". Baik jahatnya seseorang sepenuhnya tergantung pada lingkungannya termasuk keluarga dan masyarakat. Jika dikaji menggunakan teori kontrol sosial, perilaku menyimpang pada remaja merupakan hasil dari kekosongan kontrol dan pengendalian sosial. Teori ini dibangun atas dasar pandangan bahwa setiap orang cenderung untuk tidak patuh hukum atau memiliki dorongan untuk melakukan pelanggaran hukum ${ }^{21}$. Alasan pemilihan teori ini didasarkan pada pandangan bahwa perilaku pengendara motor di bawah umur yang telah menyalahi aturan dalam berlalu lintas merupakan wujud dari melemahnya pengendalian sosial oleh keluarga. Karena pada dasarnya kontrol internal (dari diri sendiri dan keluarga) lebih berpengaruh daripada kontrol eksternal yang terjadi dalam masyarakat. Berdasarkan uraian latar belakang tersebut, penelitian ini bertujuan untuk membahas tentang pola perilaku remaja pasca diperbolehkannya mengendarai motor dan pengawasan orang tua dalam menyikapi fenomena pengendarai motor pada anak di bawah umur

\footnotetext{
${ }^{19}$ Chris, Hendrix. 2013. Mengkaji Penyebab Serta Upaya Pencegahan dan Penindakan Para Perilaku Berkendara yang Beresiko Pada Remaja. Inquiry Jurnal Ilmiah Psikologi, vol 6 no 2. Dari

https://www.researchgate.net/publication/333667228_Mengkaji_penyebab_serta_upaya_pencega han_dan_penindakan_para_perilaku_berkendara_yang_berisiko_pada_remaja/link/5d02c099928 51c874c64f342/download

${ }^{20}$ Saputra, Anjar Kurniawan \& Djunaidi, Zulkifli. 2014. Persepsi Anak di Bawah Umur Terhadap Keselamatan Berkendara Sepeda Motor di Perumahan Munjul (Studi Kasus RT 11 RW 05 Kelurahan Munjul Jakarta Timur Tahun 2014). Dari http://www.lib.ui.ac.id/naskahringkas/201606/S54735-Anjar\%20Kurniawan\%20Saputra

${ }^{21}$ Putra, Ida Bagus Sudarma. 2018. Sosial Control: Sifat dan Sanksi Sebagai Sarana Kontrol

Sosial. Vyavaharaduta, voluME 8, Nomor 1. Dari https://www.ejournal.ihdn.ac.id
} 


\section{METODE PENELITIAN}

Penelitian tentang pengendara motor di bawah umur ini menggunakan pendekatan kualitatif dengan desain penelitian studi kasus. Studi kasus adalah strategi yang lebih cocok bila pertanyaan suatu penelitian berkenaan dengan how dan why, bila peneliti memiliki hanya memiliki sedikit peluang untuk mengontrol peristiwa-peristiwa yang akan diselidiki, dan bilamana fokus penelitiannya terletak pada fenomena kontemporer di dalam konteks kehidupan nyata ${ }^{22}$. Fokus penelitian ini adalah peran pengawasan orang tua dalam menyikapi pengendara motor di bawah umur dan perilaku remaja pasca diperbolehkanya mengendarai motor. Subyek penelitian ini adalah pengendara motor oleh remaja pada Sekolah Menengah Pertama dengan rentang umur 13-15 tahun dan orang tua yang memiliki anak SMP dan sudah bisa mengendarai motor. Pemilihan informan dilakukan dengan teknik purposive.

Penelitian ini dilaksanakan di Desa Kenongomulyo, Kecamatan Nguntoronadi Kabupaten Magetan. Pemilihan lokasi dilakukan dengan beberapa bertimbangan, diantaranya adalah: 1) Banyaknya remaja Sekolah Menengah Pertama yang sudah mengendarai motor diwilayah tersebut, 2) Banyaknya kasus kecelakaan oleh anak di bawah umur di wilayah tersebut, hal ini dikarenakan kurangnya pengawasan dari orang tua yang memperbolehkan anaknya untuk mengendarai sepeda motor. Penelitian ini dilaksanakan pada bulan Maret-April 2020. Teknik pengumpulan data dilakukan melalui observasi di lapangan dan melakukan wawancara secara langsung kepada informan.

Adapun analisis data yang digunakan mengadopsi dari teknik analisis data yang dikembangkan oleh Miles dan Hubberman yaitu model analisis interaktif. Model analisis ini dilakukan dengan langkah pengumpulan data, reduksi data, penyajian data dan penarikan kesimpulan atau verifikasi data. Pertama, penelitian ini dilakukan dengan mengumpulkan data yang ada di lapangan. Kedua, data tersebut dipilah kembali berdasarkan dengan rumusan masalah yang telah ditentukan. Ketiga, data yang telah diperoleh disajikan dalam bentuk deskriptif dan tahap yang ke empat yaitu melakukan verifikasi data yang telah ditemukan.

\section{HASIL DAN PEMBAHASAN}

\section{Faktor Penyebab Maraknya Pengendara Motor Di Bawah Umur}

Pengendara motor di bawah umur adalah pengguna kendaraan bermotor oleh anak remaja di bawah umur 17 tahun yang secara hukum sangat dilarang karena belum memiliki Surat Izin Mengemudi (SIM) untuk berkendara di jalan. Setiap individu memiliki cara pandang tersendiri dalam melihat kepribadian dan tingkah laku orang lain. Sama halnya dengan penafsiran orang lain dalam menilai apa yang telah dilihatnya. Pengendara motor di bawah melakukan hal tersebut

\footnotetext{
${ }^{22}$ Yin, Robet.K. 2008. Studi Kasus Desain dan Metode. Jakarta: Rajawali Pers.
} 
karena adanya kesempatan, hobi, keinginan bahkan hanya meniru atau sebagai tren zaman sekarang. Padahal dalam peraturan berlalu lintas mereka belum memenuhi persyaratan yang cukup untuk berkendara.

Faktor pertama penyebab mereka menggunakan sepeda motor adalah orang tua atau pihak keluarga, karena pada dasarnya orang tualah yang memiliki wewenang untuk memfasilitasi motor kepada anaknya, baik itu untuk ke sekolah maupun untuk bermain. Saat ini semakin banyak anak-anak yang dengan mudahnya menggunakan motor karena memang dari pihak keluarga sendiri yang mengajarkan mereka menggunakan motor. Hal ini dikarenakan kekurangpahaman pihak orang tua atau keluarga terhadap aturan dalam berkendara. Pihak orang tua memang tahu bagaimana seharusnya aturan berkendara, namun ternyata tidak dipatuhi dalam kehidupan sehari-hari ${ }^{23}$. Dengan mudahnya orang tua membelikan motor untuk anaknya agar lebih mudah untuk berpergian, padahal seharusnya hal tersebut tidak dilakukan.

"saya menggunakan motor karena memang diizinkan oleh orang tua, orang tua memperbolehkan untuk menggunakan motor kemanapun saya mau, yang penting itu tidak jauh-jauh karena saya masih belum memilik SIM" (Wawancara YG, 13 tahun)

Faktor kedua dipengaruhi oleh efisiensi waktu yang digunakan. Hal ini dikarenakan jarak tempuh yang jauh akan mudah jika menggunakan motor. Bahkan penggunaan sepeda motor dianggap lebih ekonomis dibandingkan dengan menggunakan kendaraan umum.

"pakai motor karena jarak ke sekolah memang lumayan jauh, orang tua capek kalau harus antar jemput setiap hari, makanya saya diperbolehkan untuk mengendaraimotor. Selain itu juga lebih hemat jika dibandingkandenganmenggunakan kendaraan umum”, (Wawancara IS, 13 tahun).

Faktor ketiga yang mempengaruhi banyaknya pengendara sepeda motor di bawah umur adalah teman. Teman sebaya merupakan salah satu faktor yang mempengaruhi seorang individu untuk melakukan perilaku yang menyimpang dalam masyarakat ${ }^{24}$. Seorang teman akan mempengaruhi perilaku teman lainnya, apalagi pada siswa SMP yang secara mudah dapat terpengaruh dari temantemannya. Bahkan terkadang seorang anak bisa menggunakan motor karena diajarkan oleh temannya, oleh karena itu teman sangat berpengaruh dalam meningkatkan penggunaan motor.

"saya bisa naik motor karena diajari oleh teman. Waktu itu saya diajak ke lapangan lalu diajari naik motor. Akhirnya saya merasa

\footnotetext{
${ }^{23}$ Chang, Hsin-Li \& Yeh, Tsu-Hurng. 2009. Age and Contibuting Factors to Unlicensed Teen Motorcycling. Safety Science vol 47. Dari https://ir.nctu.edu.tw/bitstream/11536/7809/1/000262201500013.pdf

${ }^{24}$ Vitaro, Frank., Brendgen, Mara \& Tremblay, Richard E. 2000. Influence of Deviant Friends on Delinquency: Searching for Moderator Variabeles. Journal of Abnormal Child Psychology, vol 28. Dari https://link.springer.com/article/10.1023/A:1005188108461
} 
ketagihan dan ingin naik motor kemana-mana" (Wawancara IS, 13 tahun).

Faktor keempat adalah gaya hidup, gaya hidup juga mempengaruhi maraknya penggunaan sepeda motor pada anak-anak. Kadang siswa yang tidak bisa mengendari sepeda motor dianggap tidak gaul oleh temannya.

" ingin mengendara motor biar seperti teman-teman lainya. Karena malu jika tidak bisa mengendarai motor, sering diejek tidak gaul dan ditinggal main oleh teman-temanlainnya" (Wawancara RH, 14 tahun).

Dari uraian tersebut dapat ditarik kesimpulan bahwasanya pengendara motor di bawah umur melakukan tindakannya karena sikap dari diri sendiri, pengaruh dari teman dan lingkungan.

\section{Pengendara Di Bawah Umur Sebagai Wujud Eksistensi Remaja}

Diperbolehkannya seorang anak di bawah umur untuk menggunakan sepeda motor telah berpegaruh besar terhadap banyak aspek dalam dirinya. Diantaranya adalah pada pergaulan anak, dengan diizinkannya anak untuk mengendarai motor seorang anak memiliki jejaring pertemanan yang lebih luas. Dulunya mereka bermain hanya di sekitar lingkungan rumah, namun sekarang ini mereka dapat bermain ke luar wilayah desa bahkan luar kecamatan.

"semenjak aku bisa naik motor, aku bisa bermain ke rumah teman yang jauh. ke Kawedanan dan KecamatanTakeran" (Wawancara $Y G, 12$ tahun). "sekarang aku bisa main kemana-mana, biasanya izin orang tua hanya ke desa sebelah padahal sebenarnya lebih jauh dari situ" (Wawancara IS, 13 tahun)

Bagi anak usia remaja, mengendarai motor merupakan hal yang sangat istimewa. Dengan mengendarai motor, mereka merasa lebih percaya diri dan terlihat tampil lebih keren. Tidak jarang dari mereka yang memodifikasi motor mereka, diantaranya adalah mengubah knalpot motor, setir motor dan bentuk spion motor. Bagi mereka, memodifikasi motor adalah suatu kewajiban yang secara tidak langsung sebagai penunjuk identitas dari keberadaanya ${ }^{25}$.

"bisa naik motor menurut saya hal yang sangat menyenangkan.

Tidak terlihat ketinggalan jaman dibandingkan teman-teman. Dan pastinya saya juga merasa lebih percaya diri dari sebelumnya" (Wawancara IS, 13 tahun)

Diperbolehkannya seorang mengndarai motor, tentunya juga berdampak negatif terhadap pola perilaku mereka. tidak jarang dari mereka yng mengenal trek-

\footnotetext{
${ }^{25}$ Kurniasih, Dewi \& Arninputranto, Wibowo. 2019. Analisis Perilaku dan Lingkungan Berkendara Sepeda Motor Pada Pelajar SMA di Surabaya Untuk Menentukan Metode Sosialisasi dan Pembelajaran Safety Riding yang Efektif. Jurnal Pendidikan Profesional. Dari http://p3m.ppns.ac.id/wp-content/uploads/2019/08/2.Analisa-Perilaku-dan-LingkunganBerkendara-Sepeda-Motor.pdf
} 
trekan, balap liar bahkan tergabung dalam kelompok tersebut. Hal ini biasanya terlihat ketika sore hari, mereka memilih jalan desa untuk melakukan aksinya. Pelaku dari aksi trek-trekan ini rata rata didominasi oleh remaja usia 13-15 tahun atau pada jenjang Sekolah Menengah Pertama.

"biasanya aku ikut trek-trekan kalau diajak sama temenku, ke tempat

yang agak sepi. misalnya daerah sawah soalnya biar orang tuaku nggak tau" (Wawancara RH, 14 tahun)

Jika dicermati dari perspektif perkembangan remaja, pada sekitar umur 1315 tahun seorang ada masih berada pada tahap remaja awal. Dimana pada tahap tersebut seaorang anak belum mengalami perkembangan emosi yang matang dan kemampuan kognitifnya belum berfungsi secara baik. Secara psikologis, masa remaja adalah usia dimana individu berintregasi dengan masarakat dewasa, usia dimana anak tidak lagi merasa di bawah tingkat orang-orang yang lebih tua melainkan berada dalam tingkat yang sama, sekurang-kurangnya dalam masalah integrasi dalam masyarakat (dewasa) mempunyai aspek efektif, kurang lebih berhubungan dengan masa puber, termasuk juga perubahan intelektual yang mencolok ${ }^{26}$. Pada masa tersebut, seorang remaja berada dalam posisi mencari jati diri dalam masyarakat dan selalu ingin mencoba hal-hal yang baru yang mereka anggap menyenangkan ${ }^{27}$. Jika dikaitkan dengan pengendara motor di bawah umur, maka jelaslah sudah bahwa hal tersebut merupakan upaya remaja untuk mencari jati diri dan eksistensi di masyarakat.

\section{Pengawasan orang tua dalam menyikapi fenomena pengendarai motor pada anak di bawah umur}

Perilaku anak-anak di bawah umur, tentunya tidak lepas dari bagaimana orang tua mengasuhnya. Karena sejatinya orang tua memiliki peranan yang sangat penting dalam pembentukan perilaku anak. Keluarga merupakan unit terkecil dari lembaga-lembaga sosial. Dalam keluargalah anak pertama kali bersosialisasi dan mendapatkan pendidikan dari orang tuanya secara informal. Anak yang dibesarkan dalam keluarga yang mengalami disfungsi mempunyai resiko lebih tinggi untuk bergantung tumbuh kembang jiwanya, daripada dibesarkan dalam keluarga yang harmonis. Peran keluarga dalam pembentukan kepribadian ataupun perilaku anak itu sangatlah penting sebagai tempat utama atau pertama kali. Kecenderungan perilaku seorang anak secara keseluruhan tergantung pada bagaimana pola asuh dan

\footnotetext{
${ }^{26}$ Rathinam, Chandrasekar. 2017. Aelf Reported Motocycle Riding Behavior Among School Children in India. Accident Analiysis and Prevention vol 39 no 2. Dari https://www.researchgate.net/publication/6747205_Selfreported motorcycle riding behavior among school children in India

${ }^{27}$ Ratnasari, F. Kumaat, Lucky T. \& Mulyadi. 2014. Hubungan Karakteristik Remaja Dengan Kejadia Kecelakaan Lalu Lintas pada Komunitas Motor Sulut King Community (SKC) Manado. Jurnal keperawatan. Dari Https://www.ejournal.unsrat.ac.id
} 
kontrol yang diterapkan oleh orang tuanya ${ }^{28}$. Adanya komunikasi di dalam keluarga antara orang tua dan anak menjadikan suatu jembatan agar anak tidak salah langkah dalam tindakan penyimpangan sosial.

Perilaku pengendara motor di bawah umur merupakan fenomena yang sekarang terjadi di kalangan masyarakat. Kurangnya pengawasan dari orang tua merupakan salah satu hal yang perlu diperhatikan lebih lanjut. Ada beberapa alasan mengapa orang tua mengizinkan anaknya untuk mengendarai motor. Alasan yang pertama, jarak rumah ke sekolah yang relatif jauh.

"saya memperbolehkan dia menggunakan motor karena jarak rumah

ke sekolah yang agak jauh, kalau saya antar jemput setiap hari capek.

Karena kebetulan saya kerja di Madiun" (Wawancara SS, 39 tahun)

Memang tidak dapat dipungkiri bahwasanya Desa Kenongomulyo merupakan daerah yang lumayan jauh dari sekolah menengah pertama maupun sekolah menengah atas. Jarak terdekat sekolah dari Desa ini sekitar 2 KM. Belum lagi letaknya yang berada di perbatasan kota, menyebabkan banyaknya orang tua yang menyekolahkan anaknya ke luar daerah.

Alasan kedua, dengan mengendarai sepeda motor maka akan menghemat pengeluaran dan dianggap lebih ekonomis jika dibandingkan naik kendaraan umum. Melalui observasi awal yang telah peneliti lakukan, memang jarang sekali adanya angkutan umum yang melewati daerah Kenongomulyo. Bahkan belum tentu ada yang lewat setiap jamnya.

"biayanya lebih murah kalau mereka naik motor sendiri, jadi bisa

lebih menghemat pengeluaran" (Wawancara TN, 40 tahun).

Alasan ketiga, melatih anak agar lebih mandiri. Informan TN (40 tahun) menyatakan "saya memperbolehkan anak naik motor itu agar mereka lebih mandiri dan tidak bergantung pada orang lain". Alasan selanjutnya, merasa malu jika anaknya tidak bisa mengendarai motor, infoman YT (39 tahun) menyatakan "sebenernya saya kurang berkenan melihat anak saya mengendarai motor, tapi saya kasihan melihatnya, seperti ketinggalan dibandingkan dengan temantemannya".

Bagi orang tua yang mengizinkan anaknya mengendarai motor, mereka memiliki beberapa cara untuk selalu mengawasi anak-anak mereka. Diantaranya adalah membatasi waktu-waktu dalam mengendarai motor, memberi batasan kemana saja mereka bisa mengendarai motor, memberi saku yang sewajarnya agar mereka tidak dapat membeli bensin untuk bepergian yang lebih jauh dan selalu menasehati mereka. Tetapi tidak jarang terdapat orang tua yang membebaskan anaknya untuk melakukan apa saja yang mereka mau, orang tua cenderung cuek

\footnotetext{
${ }^{28}$ Yaffe, Yosi. 2020. Comparing Bedouin and Jewish Parents' Parenting Styles And Practices. International Journal of Adolescence And Youth, vol 25 no 1. Dari https://www.tandfonline.com/doi/full/10.1080/02673843.2019.1577283?scroll=top\&needAccess $=$ true
} 
dan tidak begitu mempedulikan apa yang telah terjadi pada anaknya. Prinsip mereka adalah "yang penting anak merasa senang". Kesannya memang ada "pembiaran" orang tua terhadap aktivitas para remaja tersebut. Padahal hal tersebut dapat membahayakan anak, terlebih lagi kalau merenggut nyawa mereka akibat kecelakaan.

Dari penjelasan tersebut dapat ditarik kesimpulan bahwasanya pola asuh dan pengawasan yang dilakukan orang tua sangat berpengaruh terhadap tingkah laku anak. Pengasuhan yang diberikan kepada si anak harus bisa mengarahkan anak ke arah yang lebih baik serta melindungi anak dari perilaku yang kurang baik ${ }^{29}$. Pengasuhan yang dilakukan oleh orang tua bukanlah bersifat mengekang anak, tetapi lebih mengajarkan terhadap norma-norma yang ada di masyarakat. Keluarga dianggap sebagai ekologi dasar dimana perilaku seorang anak dimanifestasikan dari masa kecil dengan cara yang negatif atau positif ${ }^{30}$. Selain berpengaruh terhadap perilaku dari anak, keluarga juga memiliki pengaruh terhadap pengembangan karakter yang terjadi pada seorang anak ${ }^{31}$.

Jika dikaji dengan menggunakan teori kontrol sosial Travis Hirchi, perilaku menyimpang pada remaja ini merupakan hasil dari kekosongan kontrol dan pengendalian sosial. Teori ini dibangun atas dasar pandangan bahwa setiap manusia cenderung untuk tidak patuh hukum atau memiliki dorongan untuk melakukan pelanggaran hukum. Seseorang dapat melemah atau terputus ikatan sosial dengan masarakat, ketika fungsi lembaga kontrol sosial mengalami penurunan, seperti keluarga, sekolah, dan masyarakat ${ }^{32}$. Seseorang yang melakukan penyimpangan disebabkan oleh lingkungan sosial yang tidak berfungsi terhadap kontrol sosial dalam berperilaku. Jika dilihat dari fenomena pengendara motor di bawah umur, maka lemboga kontrol sosial yang melemah kebaradaannya adalah keluarga.

\footnotetext{
${ }^{29}$ Irmawati \& Aini, Wirdatul. 2018. Menggambarkan Manfaat Program Parenting Menurut Orang Tua di Kecamatan Lubuk Sikaping Kabupaten Pasaman. Jurnal Pendidikan Luar Sekolah, volume 1, nomor 1. Dari https://www.researchgate.net/publication/324246509 MENGGAMBARKAN_MANFAAT PRO GRAM PARENTING MENURUT_ORANG_TUA DI KECAMATAN LUBUK SIKAPING KABUPATEN PASAMAN/link/5ac6f07f4585151e80a38906/download

${ }^{30}$ Sarwar, Samiullah. 2016. Influence of Parenting Style on Children' Behavior. Journal of Education and Educational Development, volume 3 nomor 2. Dari https://files.eric.ed.gov/fulltext/EJ1161470.pdf

${ }^{31}$ Talib, M. Abdullah R \& MansoR, M. 2011. Relationship Between Parenting Style and Childrens's Behavior Problems. Asian Social Science, volume 7 nomor 12. Dari https://www.researchgate.net/publication/267845974_Relationship_between_Parenting_Style_an d_Children's_Behavior_Problems

${ }^{32}$ Putranto R. 2016. Kenakalan Remaja di Perkotaan (Studi Tentang Hubungan antara Interaksi Sosial Antarteman Sebaya dan Kontrol Sosial Sekolah di SMPN Terbuka Surabaya). Dari https://www.journal.unair.ac.id
} 


\section{KESIMPULAN}

Pengendara motor di bawah melakukan hal tersebut karena adanya kesempatan, hobi, keinginan bahkan hanya meniru atau sebagai tren zaman sekarang. Padahal dalam peraturan berlalu lintas mereka belum memenuhi persyaratan yang cukup untuk berkendara.Terdapat beberapa hal yang dapat disimpulkan terkait dengan pengendara motor di bawah umur. 1) Faktor-faktor yang mempengaruhi remaja di bawah umur menggunakan motor adalah faktor dari keluarga atau orang tua, efisiensi waktu yang digunakan, ajakan dari teman dan gaya hidup.2) Diperbolehkannya mereka mengendarai motor memiliki pengaruh terhadap pola perilakunya diantaranya adalah memiliki jejaring pertemanan yang lebih luas, mengenal dan mengikuti trek-trekan serta berani memodifikasi motor dengan dalih terlihat lebih keren. Perilaku dari remaja tersebut merupakan salah satu upaya mereka untuk mencari jati diri dan merupakan wujud eksistensi dari keberadaan mereka. 3) Orang tua memiliki peranan yang sangat penting dalam mengawasi anak. Keluarga dianggap sebagai ekologi dasar dimana perilaku seorang anak dimanifestasikan dari masa kecil dengan cara yang negatif atau positif. Pola pengasuhan yang diterapkan oleh orang tua sangat mempengaruhi pola perilaku dan juga proses pembentukan karakter anak.

\section{DAFTAR PUSTAKA}

Baharuddin. 2019. Pentingnya Pola Komunikasi Orang Tua Terhadap Perkembangan Pubertas Remaja. Jurnal Studi Gender dan Anak, Volume $12 \quad$ No $1 . \quad$ Dari https://www.researchgate.net/publication/335831848_Pentingnya_Pola_K omunikasi Orang Tua Terhadap Perkembangan Pubertas Remaja/link/5 d7ed9a092851c87c38b0335/download

Bramasta, Dandy Bayu. 2019 Berita Harian Kompas tanggal 13 Desember 2019. Viral Remaja Keramas Sambil Mengendarai Motor. Dari https://www.kompas.com/tren/read/2019/12/13/203306765/viral-remajakeramas-sambil-mengendarai-motor

Chang, Hsin-Li \& Yeh, Tsu-Hurng. 2009. Age and Contibuting Factors to Unlicensed Teen Motorcycling. Safety Science vol 47. Dari https://ir.nctu.edu.tw/bitstream/11536/7809/1/000262201500013.pdf

Chris, Hendrix. 2013. Mengkaji Penyebab Serta Upaya Pencegahan dan Penindakan Para Perilaku Berkendara yang Beresiko Pada Remaja. Inquiry Jurnal Ilmiah Psikologi, vol 6 no $2 . \quad$ Dari https://www.researchgate.net/publication/333667228_Mengkaji_penyebab _serta_upaya_pencegahan_dan_penindakan_para_perilaku_berkendara_ya ng berisiko pada remaja/link/5d02c09992851c874c64f342/download

Damron, Jessica. 2011. The Development of devian in adolescents: The Influence Of Students Characteristics and School Climate, Electronic Theses and Dissertations of University Louisville. Dari https://pdfs.semanticscholar.org/47b4/02044fae9df4c0026ef2c7874b6d43d ddd75.pdf 
Family Context and Adolescent Risky Sexual Behavior: an Examination of the Influence of Family Structure, Family Transitions and Parenting. Journal of Youth and Adolescence. Dari https://link.springer.com/article/10.1007/s10964-020-01231-z

Irmawati \& Aini, Wirdatul. 2018. Menggambarkan Manfaat Program Parenting Menurut Orang Tua di Kecamatan Lubuk Sikaping Kabupaten Pasaman. Jurnal Pendidikan Luar Sekolah, volume 1, nomor 1. Dari https://www.researchgate.net/publication/324246509_MENGGAMBARK AN MANFAAT PROGRAM PARENTING MENURUT ORANG TU A_DI_KECAMATAN_LUBUK_SIKAPING_KABUPATEN_PASAMA N/link/5ac6f07f4585151e80a38906/download

Isa, Mohd Hafzi. Sarani, Rohayu. Jawi, Zulhaidi Mohd \& Wong, Shaw VOON. 2011. Injurity Severity Analysis of Accident Involving Young Motorcycle in Malaysia. Journal of the Eastern Asia Society Transportasion Studies, vol 9.9 Dari https://www.researchgate.net/publication/280940108 Injury Severity An alysis_of_Accidents_Involving_Young_Motorcycle_Riders_in_Malaysia

Kurniasih, Dewi \& Arninputranto, Wibowo. 2019. Analisis Perilaku dan Lingkungan Berkendara Sepeda Motor Pada Pelajar SMA di Surabaya Untuk Menentukan Metode Sosialisasi dan Pembelajaran Safety Riding yang Efektif. Jurnal Pendidikan Profesional. Dari http://p3m.ppns.ac.id/wp-content/uploads/2019/08/2.Analisa-Perilaku-danLingkungan-Berkendara-Sepeda-Motor.pdf

Leong, QM, Tsung Shyen, KG, Appasamy, V., dan Chiu, MT. 2011. Young Adult and Riding Position: Factors That Affect Mortality Among Inpatient Adult Motorcycle Casualties: A Major Trauma Center Experience. World J Surg, Vol 33 No 4. Dari https://www.ncbi.nlm.nih.gov/pubmed/19184191

Manuhoro, Agasetyo. Purnaweni, Hartuti \& Rengga, Aloysius. 2016. Implementasi Kebijakan Batas Usia Terendah Pengemudi Motor Di Kota Semarang, Journal of Public Policy, volume 2 No 1. Dari https://ejournal3.undip.ac.id/index.php/jppmr/article/viewFile/10447/1014 $\underline{6}$

Maulana, Aditya. 2019. Berita harian kompas tanggal 30 Agustus 2019. Anak Di Bawah Umur Jadi Pelaku dan Korban Kecelakaan Lalu Lintas. Dari https://otomotif.kompas.com/read/2019/08/30/063200315/anak-di-bawahumur-jadi-pelaku-dan-korban-kecelakaan-lalu-lintas

McCann, Damhnat. Bull, Rosalind \& Winzenberg, Tania. 2012. The Daily Patterns Of Time Use For Parents Of Children With Complex Nedds: A Systematic Review. Journal Of Child Healts Care, Volume 16, Issue 1. Dari https://journals.sagepub.com/doi/10.1177/1367493511420186

Nordfjærn, T., Jorgensen, S., \& Rundmo, T. (2012). Cultural and sociodemographic predictors of car accident involvement in Norway, Ghana, Tanzania and Uganda. Safety Science vol 50 no 9. Dari https://www.sciencedirect.com/science/article/pii/S0925753512001130

Oxley, Jennifer. Ravi Mano Deepa. Yuen, Jeremy \& Hoareau, Eiffe. 2013. Indentifiying Contributing Fatal and Serious Injury Motorcycle Involving Children in Malaysia, An Adv Automotif Medichine, volume 57. Dari https://www.ncbi.nlm.nih.gov/pmc/articles/PMC3861809/\# 
Perepjolkina, V., \& Renge, V. (2013). Drivers' age, gender, driving experience, and aggressiveness as predictors of aggressive driving behavior. Journal of Pedagogy and Psychology "Signum Temporis", vol 4 no 1. Dari https://www.semanticscholar.org/paper/Drivers\%E2\%80\%99-Age\%2CGender\%2C-Driving-Experience\%2C-and-as-of-PerepjolkinaRe\%C5\%86\%C4\%A3e/52521213b6f1ed7dbe8d68f90ba3c8ca2d17e465

Piyapromdee, Urawit. Adulyanukosol, Varinthorn \& Lewsisirat, Supphamard. 2015. Increasing Road Traffic Injuries in Underage Motorcyclists. JRCOST vol 39 no

2.Dari https://pdfs.semanticscholar.org/0432/cd84d4f19f57baf97c2637a7 a871a4ee7e63.pdf

Putra, Ida Bagus Sudarma. 2018. Sosial Control: Sifat dan Sanksi Sebagai Sarana Kontrol Sosial. Vyavaharaduta, voluME 8, Nomor 1. Dari https://www.ejournal.ihdn.ac.id

Putranto R. 2016. Kenakalan Remaja di Perkotaan (Studi Tentang Hubungan antara Interaksi Sosial Antarteman Sebaya dan Kontrol Sosial Sekolah di SMPN Terbuka Surabaya). Dari https://www.journal.unair.ac.id

Rathinam, Chandrasekar. 2017. Aelf Reported Motocycle Riding Behavior Among School Children in India. Accident Analiysis and Prevention vol 39 no 2. Dari https://www.researchgate.net/publication/6747205_Selfreported motorcycle riding behavior among school children in India

Ratnasari, F. Kumaat, Lucky T. \& Mulyadi. 2014. Hubungan Karakteristik Remaja Dengan Kejadia Kecelakaan Lalu Lintas pada Komunitas Motor Sulut King Community (SKC) Manado. Jurnal keperawatan. Dari Https://www.ejournal.unsrat.ac.id

Saputra, Anjar Kurniawan \& Djunaidi, Zulkifli. 2014. Persepsi Anak di Bawah Umur Terhadap Keselamatan Berkendara Sepeda Motor di Perumahan Munjul (Studi Kasus RT 11 RW 05 Kelurahan Munjul Jakarta Timur Tahun 2014). Dari http://www.lib.ui.ac.id/naskahringkas/2016-06/S54735Anjar\%20Kurniawan\%20Saputra

Sarwar, Samiullah. 2016. Influence of Parenting Style on Children' Behavior. Journal of Education and Educational Development, volume 3 nomor 2. Dari https://files.eric.ed.gov/fulltext/EJ1161470.pdf

Sedanayasa, Gede. Tegeh, Made \& Gading Ketut. 2015. Model Pengasuhan Analisis Transaksional (AT) untuk Menanggulangi Penyimpangan Perilaku Seksual di Kalangan Remaja Kabupaten Buleleng (Studi Pada Sekolah SMP/SMA yang Memiliki Siswa Terindikasi). Jurnal Sosial dan Humaniora, Vol $\quad 4 \quad$ No $41 . \quad$ Dari https://ejournal.undiksha.ac.id/index.php/JISH/article/view/4925/3712

Steele, Megan E., Simons, Leslie Gordon., Sutton, Tara \& Gibbons, Frederick. 2020.

Talib, M. Abdullah R \& MansoR, M. 2011. Relationship Between Parenting Style and Childrens's Behavior Problems. Asian Social Science, volume 7 nomor 12.

Dari

https://www.researchgate.net/publication/267845974_Relationship_betwe en_Parenting_Style_and_Children's_Behavior_Problems 
Utami, Adristinindya Citra Nur \& Raharjo, Santoso Tri. 2019. Pola Asuh Orang Tua dan Kenakalan Remaja, Jurnal Pekerjaan Sosial, volume 2 nomor 1. Dari https://www.jurnal.unpad.ac.id

Vitaro, Frank., Brendgen, Mara \& Tremblay, Richard E. 2000. Influence of Deviant Friends on Delinquency: Searching for Moderator Variabeles. Journal of Abnormal Child Psychology, vol 28. Dari https://link.springer.com/article/10.1023/A:1005188108461

Wada, Tomoki. Nakahara, Shinji. Bounta, Bouasone. Phommahaxay, Kheumai \& Phonelervong, Vanhnasith. 2015. Road Traffic Injury Among Child Motorcyclist in Vientiane Capital, Laos: A Cross-Sectional Study Using A Hospital-Based Injury Surveillance Database. International Journal of Injury and Safety Promotion. Volume 24 issue 2. Dari https://www.tandfonline.com/doi/abs/10.1080/17457300.2015.108072 $\underline{8}$

Wiradiadmaja, Agung. 2020. Parenting Education: Building Character and Holding in Millenial Mental Problems, Advances In Social Scienci, Educational and Humanities Research, vol 404. Dari https://www.atlantis-press.com/proceedings/icossei-19/125934688

World Health Organization (WHO). 2011. Youth and Road Safety. Dari https://www.who.int/management/programme/ncd/Youth\%20and\%20 Road\%20Safety.pdf

Yaffe, Yosi. 2020. Comparing Bedouin and Jewish Parents' Parenting Styles And Practices. International Journal of Adolescence And Youth, vol 25 no 1.

Dari https://www.tandfonline.com/doi/full/10.1080/02673843.2019.157728 3? scroll=top\&needAccess $=$ true

Yin, Robet.K. 2008. Studi Kasus Desain dan Metode. Jakarta: Rajawali Pers. 